ISSN: 2224-0616

Int. J . Agril. Res. Innov. \& Tech. 7 (1): 64-70, J une, 2017

Available online at http:// www.ijarit.webs.com

\title{
EFFECT OF APICAL DOMINANCE ON BUD TAKE IN CITRUS VEGETATIVE PROPAGATION
}

\author{
M. Mataa', P. Cheelo ${ }^{1 *}$, D. Lungu' ${ }^{1}$ and T. Kinkese ${ }^{2}$ \\ Received 30 April 2017, Revised 24 May 2017, Accepted 26 June 2017, Published online 30 June 2017
}

\begin{abstract}
The objective of the study was to identify the grafting method, which will have a higher success rate of scion development. The study was conducted at Mount Makulu Central Research station in Chilanga, Zambia (1533'S / 28॰11'E) from April 2010 to November 2011. The study had 4 vegetative propagation methods that varied in the treatment of the rootstock and scion. The four methods were Standard T- budding (STB); Modified TBudding with decapitation (TBD); T- budding with scion bending (TBB); Crown grafting (CG). Bud take, shoot growth, leaf emergence and Leaf area index were measured up to 11 weeks after treatment (WAT). With CG there was $100 \%$ bud take. STB had a bud take of $58.3 \%$. TBD had a bud take of $50 \%$. The lowest bud take percentage was recorded in TBB, which had a bud take of $41.7 \%$. At 5 weeks the STB and TBB treatment had shoot length of 0.7 and $1.0 \mathrm{~cm}$ respectively which were the shortest; this was followed by the CG treatment at $15.3 \mathrm{~cm}$ and the modified TBD with apical shoot decapitation $(21.7 \mathrm{~cm})$. STB shoots did not start growing until about 5 weeks, which was 2 weeks after the rootstock was cut off. At 5 weeks, the TBB and STB were yet to form leaves. The CG had close to 20 leaves and the TBD had almost 15.2 leaves. At the end of 11 weeks, the TBB had the highest number of leaves. Across the grafting methods; the Leaf area exhibited a pattern similar to leaf number; it kept on doubling every 2 weeks to until the $9^{\text {th }}$ week after which the increase was negligible. At 11 weeks, the highest leaf area was in the TBD followed by the STB and lowest in the CG treatment.
\end{abstract}

Keywords: Apical Dominance, Citrus Fruit, Grafting, Vegetative Propagation

${ }^{1}$ Department of Plant Sciences, School of Agricultural Sciences, University of Zambia, P.O. Box 32379, Lusaka, Zambia

${ }^{2}$ University of Cape Town, Faculty of Science, Department of Environment and Geographical Science, African Climate and Development Initiative (ACDI), Private Bag X3, Rondebosch, Cape Town, South Africa

*Corresponding author's email: pcheelo@yahoo.com (P. Cheelo)

\section{Introduction}

Citrus fruit production is among the top in the ranks in terms of the world fruit production (FAO, 2013). The major producers of oranges in the world are China, Brazil, the United States of America, Mexico and Spain. Citrus farming is being initiated in new zones as production in the old areas is decreasing due to conversion of agricultural land to human settlements as a result of rapid urbanization, emergence of new disease and the abandonment of plantations injudiciously farmed (Ladaniya, 2008). The prime concern in increasing production is overcoming the various problems affecting the production of these citrus depending on the agro climate of that part of the world (Ladaniya, 2008).

Citrus fruit has great nutritional and economical importance (Walter, 1992). They are an important source of carbohydrates, vitamin A, C, and fiber. The fruits are processed into various products such as perfume, alcohol manufacture and stock feed (supplying up to 8\% crude protein) Morton and Miami, 1987). The Southern part of Africa has the potential to contribute significantly to world citrus production especially the offseason supplier of sweet oranges (Citrus sinensis) (USDA, 2008). Despite the nutritional benefits, fruit consumption in developing countries such as Zambia is still low (Simon, 2014). As a region, Southern Africa is the world's leading and indeed dominant supplier of off-season fruits (Jaffee, 1999). Exports from Southern Africa are dominated by South Africa followed by Zimbabwe, Swaziland and Mozambique (USDA, 2008). According to Jaffee (1999), the citrus subsectors of Zambia and Malawi are insignificant due to production and comparatively low quality and therefore not traded internationally. Among the major problems, limiting production of citrus is lack of access to high quality planting material (Makorere, 2014). 
Henceforth, this study was done with the main aim of evaluating the effect of apical dominance on bud take using different grafting methods. The specific objective was to help identify the grafting method, which will have a higher success rate of scion development.

Historically, the development of nursery techniques was aimed at overcoming environmental constraints (Mudge et al., 2009; Melnyk and Meyerowitz, 2015). Nurserymen seek to produce large numbers of high quality marketable trees in the shortest possible time (Melnyk and Meyerowitz, 2015; Hartmann et al., 1990). This is made possible by the continued testing and adopting new methods of grafting. Several grafting methods exist with different growth rates of different tree crops grown on different types of root stock (Garner and Saeed, 1976).

Apical dominance has been defined as the control exerted by the shoot apex over outgrowth of the lateral buds (Cline, 1997). Apical dominance occurs in many plants, for the horticulturist, manipulating this natural response by processes such as pruning and grafting allows the horticulturist to determine the shape, size and productivity of many fruiting trees and bushes (McSteen, 2009; Acquaah, 2009). Apical dominance is a well-known phenomenon in which it has been traditionally postulated that auxin traveling basipetal from the shoot apex suppresses the outgrowth of axillary buds (Thimann and Skoog, 1933; Leyser, 2003). If a shoot is decapitated, the axillary buds are activated. If auxin is applied to the cut end of the shoot, suppression of buds reoccurs. This is a classical example of a developmental correlation where one organ of a plant affects another organ (Cline, 1997). However, measurements of the speed of translocation of these growth regulators and detection of the onset of changes in the activity of the target buds point to the involvement of other more rapid substances or conditions (Morris et al., 2005). The nature of this decapitation-induced long-distance signals that trigger initial bud outgrowth remains elusive (Morris et al., 2005; Loeb, 1918). Moreover, the transition from dormancy to active growth has been shown to be modulated by decapitation.

The centrality of decapitation in the transition from dormancy to active growth is important to plant propagation because most vegetative propagation methods (budding and grafting) involve plant excision or decapitation. However, interpreting the mechanisms or responses in perennial plants based on observation in annual plants may be more challenging given the outlined differences in development cycles. Apical dominance studies have shown the involvement of auxins and cytokinins synthesis and translocation. Additionally, decapitation has the effect of disturbing water movement and any materials transported therein and this may have more dramatic effects in grafting. This is particularly important in the early stages of development when the vascular union has not yet occurred. Depending on the climate and season vascular connection may take up to 6 weeks after grafting (Hartmann et al., 1990).

In this study, we looked at different vegetative propagation methods that varied in the treatment of the rootstock and scion and postulated on the effects these treatments may have exerted on the developing buds with reference to auxins and cytokinins.

\section{Materials and Methods}

\section{Location description}

The study was conducted at Mount Makulu Central Research station in Chilanga, Zambia (1533'S / 28॰11'E) from April 2010 to November 2011. The research station is located at about $1300 \mathrm{~m}$ above sea level in the agro-ecological region II of Zambia. The mean annual temperature in this region was $23^{\circ} \mathrm{C}$ to $25^{\circ} \mathrm{C}$. The region receives medium annual rainfall of between $800-1000 \mathrm{~mm}$. The meteorological data are shown in Table 1 below.

Table 1. Climatic data during the grafting period for the experimental site Mt Makulu, Chilanga Zambia.

\begin{tabular}{llllll}
\hline Month & July & August & September & October & November \\
\hline Maximum Temp $\left({ }^{\circ} \mathrm{C}\right)$ & 20.0 & 24.7 & 30.7 & 31.6 & 27.1 \\
Minimum Temp $\left({ }^{\circ} \mathrm{C}\right)$ & 12.0 & 10.2 & 15.0 & 18.1 & 17.4 \\
Relative Humidity $(\%)$ & 88.0 & 57.0 & 51.4 & 50.0 & 68.2 \\
Evaporation & 2.9 & 4.8 & 7.6 & 8.5 & 5.2 \\
Rainfall & - & - & - & - & 8.8 \\
\hline
\end{tabular}

\section{Plant materials}

Rough lemon root stock (Citrus jambiri), the rootstock commonly used in Zambia for grafting citrus, was used. The seeds for the rootstock were obtained from a private grower within the area.
The trees were vigorous and healthy without any history of infectious diseases. The seeds were planted in April 2010 and allowed to grow for about 1 year. Propagation was done in J uly 2011 when the stem diameters were about $1.5 \mathrm{~cm}$ in diameter. 


\section{Grafting methods}

Four grafting methods were used; these were Crown grafting (CG), Standard T budding STB), T- budding with bending of the stem (TBB) and T- budding with the decapitation of the apical bud (TBD).

\section{Crown grafting}

The graft was prepared by making two clean cutsone on each side of the sliced end of the scion thereby giving it a flute shape (Hartman et al., 1990). The union is stabilized or kept in place by tying it with a strip, of course, Tsugigi grafting tape (Engei Hyo, Tokyo). The scion was then covered with waterproof but air exchange capable membrane tape 'Buddy tape' (Aglis Co. Chiyoda $\mathrm{ku}$, Japan).

\section{Standard $\mathrm{T}$ budding}

Budding was done at 15 to $20 \mathrm{~cm}$ from the ground. The first incision was made on the rootstock by a downward cut about $2-3 \mathrm{~cm}$ long followed by a cross cut on top of the first cut to get a T shape. After making the 'T' shaped cut, the bark is opened up with the ends of the budding knife and, a bud shaped like a shield is extracted from a healthy mother tree.

\section{T budding with decapitated stock}

The stem was cut at the desired height (15- 20 $\mathrm{cm}$ ) followed by a horizontal cut of a length slightly longer than the anticipated length of the bud $(\approx 3 \mathrm{~cm})$. The bud was inserted in this vertical cut taking care to avoid subjecting the bud to undue pressure. The bud and the cut surface of the rootstock were then covered with a waterproof but air exchange capable grafting tape.

T budding with bending of stock

Normal budding was done as recommended in the production of citrus budded seedlings in the nursery (Hartmann et al., 1990). Stem bending was done as a post budding operation. The stem was bent by tying it to the ground using a piece of string. The bending angle was about 60 degrees; care was taken to avoid breaking the stem during the process.

\section{Experimental design}

The experiment was set up as a split plot design with time (weeks after grafting) as the main plot and grafting method as the split plot. Four grafting treatments were used; $\mathrm{T}$ budding with bent rootstock (TBB), Standard ' $T$ ' budding (STB), T-budding with stock decapitation (TBD) and cleft grafting (CG). There were 12 single tree replications of each grafting method.
The plants were potted in the same size of pots and exposed to the same kind of environment. Plants were grown in black polyethylene UV stable sleeves filled with garden soil. The polythene sleeves had a volume of $176.71 \mathrm{~cm}^{3}$ each. They were bought from Polythene Products Zambia Ltd., Zambia.

A total of 48 one year old rough lemon root stocks were budded and grafted on the same day the scion wood was collected. The scion wood was collected from a private orange orchard (Mwangala's farm) in the same locality near Lusaka. The source trees were 12 years old. The budding and grafting were done by a professional nurseryman. The grafting was done in partial shade under shade trees and the plants were allowed to grow under these same conditions. Standard nursery management practices such as weeding, pest and disease control were done as recommended.

\section{Data collection and analysis}

The variables that were measured were: Bud take, Scion length and Leaf area. Bud 'take' was measured by counting the number of plants that were budded against those whose buds survived and established. The counts were taken at three weeks after grafting.

Scion length determination was done by using a ruler and vernier caliper on a weekly basis. Leaf area was measured by determining leaf length and leaf width of the plants and then multiplying the products with a correction factor of 0.75 .

The data was subjected to analysis of variance and separation of the means (Sokal and Rolfe, 1981). GENSTAT 14 and Microsoft Excel spread sheet software were used in analyzing the data.

\section{Results}

The treatments had a significant effect on bud take, shoot initial growth and leaf area expansion. There was significant interaction between the different method and time of determination. The results obtained showed significant effects of grafting method on graft success and shoot development especially in the early shoot development phase. CG had the highest bud take, followed by the TBD whereas STB had the lowest bud take. The TBB treatment was intermediate.

\section{Graft success}

Table 2 shows propagation success. With Crown grafting all of the 12 plants, which were grafted were successful representing $100 \%$ bud take. Standard 'T' budding with upright rootstock had a success rate of $58.33 \%$ of the grafted plants. Budding with decapitated rootstock had a bud take of $50 \%$. The lowest bud take percentage was recorded in ' $\mathrm{T}$ ' budding with bent rootstock, which had a bud take of $41.67 \%$. 
Table 2. Graft success rate (bud take) in Orange (Citrus sinensis var Washington navel) subjected to four grafting methods on rough lemon (Citrus jambiri). Bud take was measured three weeks after propagation.

\begin{tabular}{llll}
\hline Grafting method & $\begin{array}{l}\text { Number of plants } \\
\text { grafted }\end{array}$ & $\begin{array}{l}\text { Number of plants with } \\
\text { bud take }\end{array}$ & $\begin{array}{l}\text { Success rate (bud } \\
\text { take) (\%) }\end{array}$ \\
\hline T budding with bent Stock (TBB) & 12 & 5 & 41.7 \\
Standard 'T' budding (STB) & 12 & 7 & 58.3 \\
Crown grafting(CG) & 12 & 12 & 100.0 \\
T' budding with decapitation (TBD) & 12 & 6 & 50.0 \\
\hline
\end{tabular}

\section{Scion growth}

The data representing early scion development are shown in Table 4 and this covered the period from week 5 to week 11 after grafting. Across grafting methods, there was a consistent increase in shoot length, increasing from $9.69 \mathrm{~cm}$ at week 5 to $32.08 \mathrm{~cm}$ at week 11 . The $\mathrm{T}$ budding with decapitation exhibited the rapid and highest shoot length, which was $21.72 \mathrm{~cm}$ at week 5 to
$35.31 \mathrm{~cm}$ at end of the observation period. The STB and TBB had the slowest shoot growth. The CG was intermediate. There was some interaction between time and grafting method. The STB was slow growing particularly in the early stage up to 7 weeks after grafting but as they progressed, they exhibited higher growth. The tallest plants were found in the TBD treatment. The results are presented below in table 3.

Table 3. Effect of grafting method and time on scion length in Orange (Citrus sinensis) grafted on Rough lemon (C. jambiri) using different grafting methods.

\begin{tabular}{llllll}
\hline Parameter & \multicolumn{4}{c}{ Average scion length $(\mathrm{cm})$ plant ${ }^{-1}(\mathrm{n}=12)$} & LSD \\
\hline Time(weeks) & 5 & 7 & 9 & 11 & 2.03 \\
& 9.69 & 17.14 & 27.95 & 32.08 & \\
Grafting method & CG & STB & TBB & TBD & 1.86 \\
& 23.68 & 17.50 & 17.25 & 28.42 & \\
Timex grafting method & CG & STB & TBB & TBD & \\
5 & 15.29 & 0.70 & 1.03 & 21.72 & \\
7 & 21.40 & 8.90 & 12.35 & 25.89 & \\
9 & 26.95 & 28.43 & 25.62 & 30.78 & 3.77 \\
11 & 31.08 & 31.96 & 29.99 & 35.31 & \\
\hline
\end{tabular}

CG Crown grafting; STB- Standard T budding; TBB- T budding with bending of stem and TBD- T budding with Rootstock decapitation.

\section{Leaf emergence}

The number of leaves plant-1 increased with time, increasing from 8.22 leaves at 5 weeks to about 22 leaves at 11 weeks (Table 4). The CG treatment and TBD had the highest number of leaves across the study period, averaging about 20 leaves plant1. The STB and TBB had significantly fewer leaves (almost half of the other 2 treatments).
In the early stages of development the STB and TBB exhibited slight defoliation. There was significant time $\mathrm{x}$ grating method interaction. The CG had the highest number of leaves at 5 weeks but the increase was low and in the 7 weeks, there was a slight defoliation. The TBB had the highest number of leaves at the end of the study; the difference was significantly higher compared to the other 3 treatments.

Table 4. Effect of grafting method and time on leaf number in Orange (Citrus sinensis) grafted on Rough lemon (C. jambiri) using different grafting methods.

\begin{tabular}{llllll}
\hline Parameter & \multicolumn{3}{c}{ Number of leaves plant ${ }^{-1}(\mathrm{n}=12)$} & LSD \\
\hline Time (weeks) & 5 & 7 & 9 & 11 & 1.30 \\
& 8.22 & 12.31 & 18.92 & 21.19 & 1.14 \\
Grafting method & CG & STB & TBB & TBD & \\
& 19.57 & 9.63 & 10.63 & 20.84 & \\
Time x grafting method & CG & STB & TBB & TBD & \\
5 & 19.41 & - & - & 15.23 & \\
7 & 16.98 & 4.98 & 7.69 & 19.90 & \\
9 & 19.51 & 15.84 & 17.56 & 22.76 & 2.34 \\
11 & 22.38 & 19.02 & 17.88 & 25.48 & \\
\hline
\end{tabular}

CG Crown grafting; STB- Standard T budding; TBB- T budding with bending of stem and TBD- T budding with Rootstock decapitation. 


\section{Changes in leaf a rea}

Effects of treatments on leaf area are shown in Table 5. The data for leaf area showed some increase with time. The increase was from $114 \mathrm{~cm}$ to $454 \mathrm{~cm} 2$. The increase was consistent over the study period but with greater increase occurring between the 7 and 9 week period. The TBD at 435 $\mathrm{cm}^{2}$ had the highest leaf area, followed by CG and then the STB and TBB. The leaf area of STB and TBB was less than $50 \%$ of the high leaf area treatment.

Table 5. Effect of grafting method and time on leaf area in Orange (Citrus sinensis) grafted on Rough lemon (C. jambiri) using different grafting methods.

\begin{tabular}{llllll}
\hline Parameter & \multicolumn{4}{c}{ Average leaf area plant-1 $\left(\mathrm{cm}^{2}\right)(\mathrm{n}=12)$} & LSD \\
\hline Time (weeks) & 5 & 7 & 9 & 11 & \\
& 114 & 211 & 436 & 454 & 67.0 \\
Graftingmethod & CG & STB & TBB & TBD & \\
& 362 & 211 & 206 & 435 & 57.3 \\
Timex grafting method & CG & STB & TBB & TBD & \\
5 & 277 & - & - & 243 & \\
7 & 386 & 19.0 & 69.0 & 371 & \\
9 & 396 & 421 & 394 & 532 & 118.2 \\
11 & 390 & 425 & 404 & 596 & \\
\hline
\end{tabular}

CG- Crown grafting; STB- Standard T budding; TBB- T budding with bending of stem and TBD- T budding with Rootstock decapitation.

\section{Discussion}

The response in the post scion establishment phase could be grouped into those treatments involving shoot decapitation at grafting (CG and TBD) and those that retained the apical shoot (STB and TBB). Shoot emergence and development was lowest in the TBB were visible shoot development only started about 2 weeks after decapitation of the apical shoot. Bending the shoot did not improve both bud take or early shoot development significantly. Leaf area index, which indicates efficiency in light utilization showed trends very similar to leaf emergence. Plant organs are produced in meristems in a continuous and predictable but flexible manner, phyto-hormones and transcription factors cooperate to balance meristem maintenance and organ production (Shani et al., 2006).

Although the results seem to be influenced by apical dominance effects, differences within the 2 decapitation treatments (the CG and TBD) indicate other possible influences, such as storage carbohydrate content in the grafts. The role of carbohydrates in tree productivity is well documented but not without disagreement (Goldschmidt and Golomb, 1982; Goldschmidt and Koch, 1996). It can be postulated that the CG having larger scion wood comes with higher storage reserves that the scion can be used before it has sufficient leaf development. This early development would allow for more rapid growth and early shoot development.

It has been documented that apical dominance is transduced through shoot-based auxins suppressing the synthesis of cytokinins in the shoot (Tanaka et al., 2006; Kyozuka, 2007; Cline, 1997). The involvement of other plant hormones- strigolactones; a group of terpenoid lactones (Umehara et al., 2008) unique proteins (Stafstrom and Sussex, 1992) other than the conventional ones, being involved in shoot branching is documented. Additionally most of the work on apical dominance has involved single stemmed annual dicots peas (Pisum sativum), observations from such plant may be difficult to use to explain apical dominance in woody species such as Citrus. Citrus being perennial multistemmed woody species with concurrent development of apical shoots at different shoot development stages.

For the decapitated treatments (CG and TBD) the response was, however, slightly different. The major difference was the size of the scion grafted on to the stock. The Crown graft was composed of a stem of about $3 \mathrm{~cm}$, it can be postulated that this represents a significant amount of storage reserve that could have been available to the bud (Mataa et al., 1996). T- budding with bending of the stock is supposed to ensure that the bud has full access to water and other growth substances while at the same time preventing the basipetal polar movement of inhibitive substances such as auxins from the shoot apex to the bud. Among the reasons that can be advanced for the comparatively lower bud take in budding can be that the bending represented a significant and sustained stress on the plant having been applied at onset. Additionally, the efficiency of preventing auxin movement may be low. Also due to the lifting of the bark of the flap, budding methods like the ' $\mathrm{T}$ ' budding are thought to cause considerable callus in filling and development of new cambium (Acquaah, 2009). This effect may cause a delay in wound healing and increases subsequent death of the buds. 
Coupled to this, Hartmann et al. (1990) showed with budding, the scion is considerably smaller and normally limited to one bud and a short stem piece. Therefore, any vascular differentiation from callus cells may be inhibited by lower phytohormone levels hence; wound cambium differentiation does not take place before bridging of the vascular tissue; a characteristic of the citrus trees. With budding coupled with rootstock decapitation the bud 'take' success was at $50 \%$. Decapitation of the stock could have removed the source of apical dominance completely (Cline, 2004). The significant failure in bud 'take' can be attributed to many factors. Although the involvement of apical dominance can be used to account for lower bud success, the post-grafting growth response of the shoot is contradictory. Growth is enhanced by phytohormones such as cytokinins, which are produced in root apex and it is known that they are transported acropetally from the root apex in the transpiration stream. With shoot decapitation, this is not possible but the growth in the decapitated stock was still seen to be high. It is worthwhile to note that this work was done without determining of changes in critical hormones and future studies in this direction would be insightful.

\section{Conclusion}

The study was able to find that crown grafting had higher graft take and the resulting plants comparatively exhibited more vigorous development and least apical dominance carryover effects. Additionally, the performance of the plants seems to be based on the size of the scion. Therefore, although the results indicated the influence of apical dominance, it is not sufficient to explain observed effects and possibly indicate the role of assimilating reserves influenced responses.

\section{Acknowledgements}

The authors are thanking the staff of the Department of Plant Sciences, University of Zambia for the support during the critical times of the research.

\section{References}

Acquaah, G. 2009. Horticultural Principles and Practices, Prentice Hall, Inc Simon and Schuster. A. Viacom Company, Upper Saddle River, New J ersey. 569p.

Cline, M. 2004. The role of hormones in apical dominance, New approaches to an old problem in plant development. Physiologia Plantarum. 90: 230- 237.

Cline, M.G. 1997. Concepts and terminology of apical dominance. American J. Bot. 84: 1064- 1069.
FAO. 2013. Statistical Yearbook. World Food and Agriculture. Food and Agriculture Organisation of the United Nations, Rome. 169p.

Garner, R.J. and Saeed, A.C. 1976. The Propagation of Tropical Fruit trees. Commonwealth Bureau of Horticultural and Plantation Crops, Food and Agriculture Organization of the United Nations; Commonwealth Agricultural Bureaux, Farnham Royal, Slough SLZ, 3BN, England. $567 \mathrm{p}$.

Goldschmidt, E.E. and Koch, K.E. 1996. Citrus. In: Zaminski, E., Schaffer A.A. (eds). Photoassimilate Distribution in Plants and Crops: Sink- source relationships, pp. 797823.

Goldschmidt, E.E. and Golomb, A. 1982. The carbohydrate balance of alternate bearing citrus trees and of reserves for flowering and fruiting. J. American Soc. Hort. Sci. 107: 206- 208.

Hartmann, H.T., Kester, D.E. and Davies, F.T. 1990. Plant propagation, Principles and Practices, 5 ${ }^{\text {th }}$ Edn., Prentice-Hall, Inc. Simon and Schuster Company. Englewood Cliffs, NewJ ersey, USA. pp. 318-378.

Jaffee, S. 1999. Southern African agribusiness: Gaining through regional collaboration. World Bank Publications. 424: 30-88.

Kyozuka, J. 2007. Control of shoot and root meristem function by cytokinin. Curr. Opin. Plant Biol. 10: 442- 446.

Ladaniya, S.M. 2008. Citrus fruits: biology, technology and evaluation, Academic press 525 B streetsuite,1900 San Diego CA, USA. pp. 1-6.

Leyser, O. 2003. Regulation of shoot branching by auxin. Trends Plant Sci. 8: 541- 545.

Loeb, J. 1918. Chemical basis of correlation I. Production of equal masses of sister leaves in Bryophyllum calycinum. Bot. Gaz. 65: 150174.

Mataa, M., Tominaga, S. and Kozaki, I. 1996. Seasonal changes of carbohydrate constituents in ponkan (Citrus reticulata Blanco). J. Japan. Soc. Hort. Sci. 65: 513523.

Makorere, R. 2014. An Exploration Of Factors Affecting Development Of Citrus Industry In Tanzania: Empirical Evidence From Muheza District, Tanga Region. Int. J. Food Agril. Econ. 2(2): 135.

McSteen, P. 2009. Hormonal Regulation of Branching in Grasses. Plant Physiol. 149: 46-55.

Melnyk, C.W. and Meyerowitz, E.M., 2015. Plant grafting. Current Biol. 25(5): 183-188.

Morris, S.E., Cox, M.C.H., Ross, J.J., Krisantini, S. and Beveridge, C.A. 2005. Auxin dynamics after decapitation are not correlated with the 
initial growth of auxiliary buds. Plant Physiol. 138: 1665- 1672.

Morton, L.J.F. and Miami, F.L. 1987. Orange. In: Fruits of Warm Climates. pp. 134-142. http://www.hort.purdue.edu/newcrop/mort on/orange.html.14/07/2010.

Mudge, K., Janick, J., Scofield, S. and Goldschmidt, E.E. 2009. A History of Grafting. Hort. Rev. 35: 437.

Shani, E., Yanai, O and Ori, N. 2006. The role of hormones in shoot apical meristem function. Curr. Opin. Plant Biol. 9: 484- 489.

Simon, P.W. 2014. Progress towards increasing intake of dietary nutrients from vegetables and fruits: The case for greater role of horticultural sciences. Hort. Sci. 49: 112- 115.

Sokal, R.R. and Rolfe, F.J. 1981. Biometry. $2^{\text {nd }}$ edn. W.H. Freeman and Company, New York. pp. 393-399.

Stafstrom, J.P. and Sussex, I.M. 1992. Expression of a ribosomal protein gene in axiliary buds of pea seedlings. Plant Physiol. 100: 14941502.
Tanaka, M., Takei, K., Kojima, M., Sakakibara, H. and Mori, H. 2006. Auxin controls local cytokinin biosynthesis in the nodal stem in apical dominance. Plant J. 45: 1028- 1036.

Thimann, K.V. and Skoog, F. 1933. Studies on the growth hormones of plants. III. The inhibition action of growth substance on bud development. In: Proceedings of the National Academy of Science' USA. 19: 714716.

Umehara, M., Hanada, A., Yoshida, S., Akiyama, K., Arite, T., Takeda-Kamiya N., Magome, H., Kamiya, Y., Shirasu, K. and Yoneyama, K. 2008. Inhibition of shoot branching by new terpenoid plant hormones. Nature. 455: 195- 200.

USDA. 2008. Foreign Agricultural Service report. 2008. Citrus World Markets and Trade, $(4 / 2008$.

Walter, F. 1992. The Citrus Industry. Volume 1. History, world distribution, Botany and Varieties. A centennial publication of the University of California. pp. 16-40. 